\title{
PENGARUH DOSIS PUPUK KCL TERHADAP PERTUMBUHAN DAN PRODUKSI UBI JALAR (Ipomoea batatas (L.) Lam.)
}

\author{
Onesimus Akari", Dewi Ratna Nurhayati ${ }^{* *}$ Efrain Patola** \\ *Fakultas Pertanian, Universitas Slamet Riyadi, Surakarta, E-mail: onesimusakarionesimusakari @ gmail.com \\ **Fakultas Pertanian, Universitas Slamet Riyadi, Surakarta
}

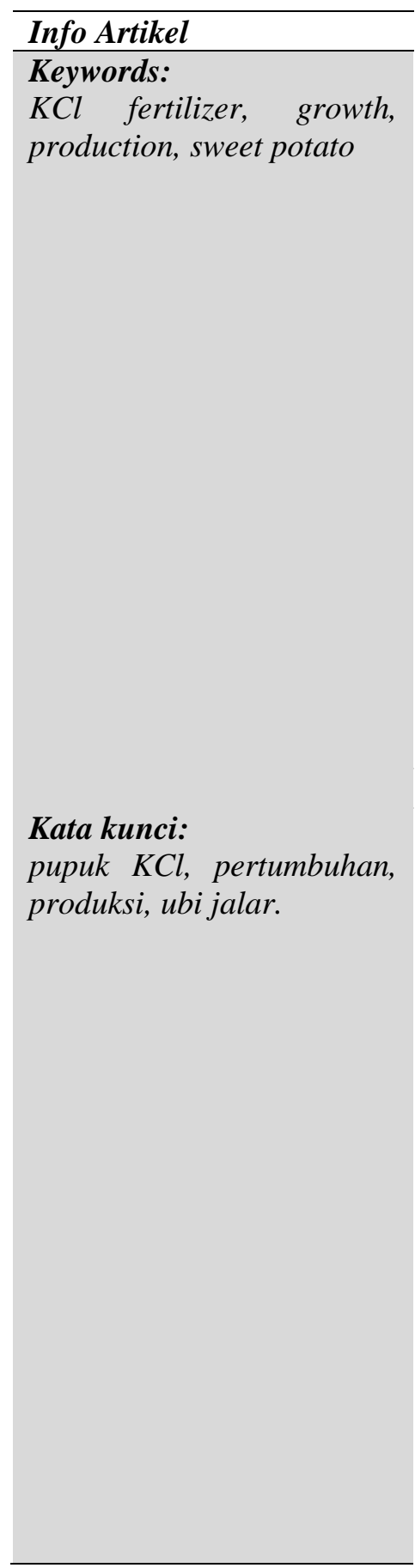

\begin{abstract}
The purpose of this research was: (1) to know the influence of $\mathrm{KCl}$ fertilizer dosages on the growth and production of sweet potato, (2) to know the best dosage of $\mathrm{KCl}$ fertilizer against growth and production of sweet potato. This study uses a Completely Randomized Block Design, consisting of 5 treatments and 5 replication. Data were analyzed by Analysis of variance, continued by Honestly Significant Diferent Test. The results of this study indicated: (1) the aplication of $\mathrm{KCl}$ fertilizer has non significant effect on the main stem length, branches number, and leaves number, (2) the application of $\mathrm{KCl}$ fertilizer has a significant effect on the fresh weight of the tubers, but non significantly on the tuber diameter, the tuber number, and the tubers length per plant, (3) the application of $\mathrm{KCl}$ fertilizer has a significant effect to healthy tuber weight, rejected tuber weight, marketable tuber weight, and fresh tuber weight per hectare, (4) the best dosage of KCl fertilizer is 150 $\mathrm{kg} / \mathrm{ha}$ because it can produce the highest fresh weight of tuber, the highest healthy tuber weight, the lowest l reject tuber weight, the lowest tuber weight the heaviest marketable, and the highest fresh tuber weight.
\end{abstract}

\section{Abstrak}

Tujuan penelitian ini adalah : (1) untuk mengetahui pengaruh dosis pupuk $\mathrm{KCl}$ terhadap pertumbuhan dan produksi ubi jalar, (2) untuk mengetahui dosis pupuk $\mathrm{KCl}$ terbaik terhadap pertumbuhan dan produksi ubi jalar. Penelitian ini menggunakan rancangan dasar Rancangan Acak Kelompok Lengkap yang terdiri dari 5 perlakuan dan 5 ulangan. Data dianalsis menggunakan analisis ragam dilanjutkan dengan uji Beda Nyata Jujur. Hasil penelitian ini menunjukkan (1) pemberian pupuk $\mathrm{KCl}$ tidak berpengaruh terhadap panjang batang utama, jumlah cabang, dan jumlah daun. (2) pemberian pupuk $\mathrm{KCl}$ berpengaruh nyata terhadap berat segar umbi per tanaman, tetapi tidak nyata terhadap diameter umbi per tanaman, jumlah umbi per tanaman, dan panjang umbi per tanaman. (3) Pemberian pupuk $\mathrm{KCl}$ berpengaruh terhadap berat umbi sehat per hektar, berat umbi afkir per hektar, berat umbi yang dapat dipasarkan, dan berat segar umbi per hektar. (4) dosis pupuk $\mathrm{KCl}$ terbaik adalah $150 \mathrm{~kg} / \mathrm{ha}$ karena dapat menghasilkan berat segar umbi tertinggi, berat umbi sehat tertinggi, berat umbi afkir terrendah, berat umbi yang dapat dipasarkan yang terberat, dan berat segar umbi tertinggi. 


\section{PENDAHULUAN}

Ubi jalar (Ipomoea batatas (L.) Lam.) yang diduga berasal dari benua Amerika, merupakan bahan makanan tambahan atau pengganti beras dan jagung sebagai bahan makanan pokok seperti di Papua dan Maluku (Rukmana, 2004)

Produksi ubi jalar di Indo-nesia memang cukup tinggi jika dibandingkan dengan beberapa negara lain, namun belum optimal. Pada tahun 2014, rata-rata produktivitas ubi jalar di Indonesia mencapai 15,19 ton/ha, jauh lebih rendah jika dibandingkan dengan potensi hasil produktivitas beberapa varietas unggul yang mencapai 35 ton/ha.

Salah satu penyebab belum optimalnya produktivitas ubi jalar adalah pemupukan dengan dosis rendah (Paturohman dan Sumarno, 2016), padahal ubi jalar sangat respon terhadap pemupukan terutama Kalium karena sangat dibutuhkan tanaman penghasil karbohidrat terutama tanaman ubi jalar (Limbeng, 2011). Menurut Sarwono (2007) fungsi Kalium antara lain adalah translokasi gula pada pembentukan pati dan protein, membantu mem-buka dan menutup stomata, memperbaiki ukuran dan kualitas umbi, menambah rasa manis pada umbi dan membantu memproduksi karbohidrat dalam jumlah yang besar.

Menurut Sumarno (1981), peningkatan produktivitas tanaman ubi jalar dipengaruhi oleh beberapa hal antara lain penggunaan sarana produksi berupa pupuk. Petani umumnya memberikan dosis pupuk yang tinggi pada tanaman ubi jalar sehingga mengakibatkan biaya produksi meningkat. Oleh karena itu, dengan penelitian ini diharapkan dapat menentukan dosis pupuk $\mathrm{KCl}$ yang tepat yang akan mencukupi kebutuhan tanaman sehingga dapat diperoleh produksi ubi jalar yang optimal.

\section{BAHAN DAN METODE}

Bahan yang digunakan, antara lain: setek pucuk tanaman ubi jalar varietas madu, pupuk kandang kotoran sapi, pupuk urea, SP-36, $\mathrm{KCl}$, pestisida.

Penelitin ini menggunakan Rancangan Acak Kelompok Lengkap yang terdiri dari 5 perlakuan dosis pupuk $\mathrm{KCl}(\mathrm{D})$, yaitu :

$\mathrm{D}_{0}=\operatorname{dosis} 0 \mathrm{~kg} / \mathrm{ha}$

$\mathrm{D}_{1}=$ dosis $50 \mathrm{~kg} / \mathrm{ha}$

$\mathrm{D}_{2}=$ dosis $100 \mathrm{~kg} / \mathrm{ha}$

$\mathrm{D}_{3}=$ dosis $150 \mathrm{~kg} / \mathrm{ha}$

$\mathrm{D}_{4}=$ dosis $200 \mathrm{~kg} / \mathrm{ha}$

Kelima perlakuan tersebut di-ulang 5 kali sehingga diperoleh 25 satuan percobaan. Data dianalsis menggunakan analisis ragam (Gaspersz, 1991; Sungandi dan Sugiarto, 1994). Analisis selanjutnya menggunakan Uji Beda Nyata Jujur pada taraf 5\% (Garspersz, 1991; Sugandi dan Sugisrto, 1994; Steel dan Torrie, 1989).

Penelitian telah dilaksanakan pada Januari sampai April 2019, di Desa Karanglo, Kecamatan Tawang-mangu, Kabupaten Karanganyar, Jawa Tengah, dengan ketinggian tempat $\pm 500 \mathrm{~m}$ di atas permukaan laut, dan jenis tanah Mediteran coklat tua.

Tanah dibersihkan dari batu-batuan dan sisa-sisa tanaman se-belumnya, kemudian dicangkul sedalam $30 \mathrm{~cm}$ dan diratakan, kemudian dibuat blok-blok sebanyak 5 blok dengan jarak antar blok $50 \mathrm{~cm}$. Masing-masing blok dibagi menjadi 5 petak dengan ukuran 3,0 x 2,0 m per petak, dan jarak antar petak $30 \mathrm{~cm}$. Jumlah seluruh petak adalah 25 petak. Masing-masing petak diberi pupuk kandang kotoran sapi $10 \mathrm{t} / \mathrm{ha}$, lalu dicampur dengan tanah secara merata dan dibiarkan inkubasi selama 1 minggu.

Bibit diambil dari setek pucuk ubi jalar varietas madu yang berumur dua bulan dengan panjang $30 \mathrm{~cm}$, kemudian ditanam dengan jarak tanam $75 \mathrm{~cm}$ x $25 \mathrm{~cm}$ dan posisi mendatar (Juanda dan Cahyono, 2002).

Penanaman bibit ubi jalar untuk bagian yang di atas tanah adalah 2 ruas batang dan yang dibenamkan dalam tanah adalah 3 ruas batang (2/3 dari panjang bibit) dengan panjang bibit $25 \mathrm{~cm}$, kemudian tanah di sekitar pangkal setek dipadatkan. Setelah selesai penanaman disiram air agar stek ubi jalar kelihatan segar dan cepat tumbuh (Rulina, 2010).

Pemupukan menggunakan pupuk Urea sebanyak $100 \mathrm{~kg} / \mathrm{ha}$ dan SP-36 sebanyak $44 \mathrm{~kg} / \mathrm{ha}$ (Supriyono et al., 1994 dalam Juanda dan Cahyono, 2002). Sedangkan pemupukan KCl sesuai dosis 
perlakuan dan diberikan 2 kali, yaitu pertama 1/3 dosis diberikan pada saat penanaman bibit setek pertama kali dan kedua $2 / 3$ dosis $\mathrm{KCl}$ pada umur 7 MST. Pemupukan dengan cara memasukan pupuk dalam alur yang dibuat memanjang di antara barisan tanaman yang berjarak $8 \mathrm{~cm}$ dari batang tanaman dann kedalaman $7 \mathrm{~cm}$. Pengamatan pertumbuhan tanaman dilakukan terhadap 3 tanaman sampel pada setiap satuan percobaan di luar tanaman ubinan. Pengamatan produksi per tanaman dilakukan terhadap 3 tanaman sampel pada setiap satuan percobaan di luar tanaman ubinan dan tanaman sampel untuk pertumbuhan. Sedangkan pengamatan per hektar dilakukan terhadap peubah produksi pada ubinan dengan luas $1,5 \times 1,5 \mathrm{~m}$.

\section{HASIL}

\section{Pertumbuhan Tanaman}

Hasil analisis ragam menunjukkan bahwa perlakuan dosis pupuk $\mathrm{KCl}$ tidak berpengaruh terhadap peningkatan panjang batang utama pada umur 5 sampai 11 Minggu Setelah Tanam (MST) ; tidak berpengaruh terhadap peningkatan jumlah cabang pada umur 5 sampai $11 \mathrm{MST}$; tidak berpengaruh terhadap peningkatan jumlah daun pada umur 5, 10, dan 11 MST ; serta berpengaruh terhadap peningkatan jumlah daun pada umur 6, 7, 8, dan 9

\section{Produksi Per Tanaman}

Hasil analisis ragam menunjukkan bahwa perlakuan dosis pupuk $\mathrm{KCl}$ tidak berpengaruh terhadap peningkatan diameter umbi per tanaman pada umur 12 MST ; tidak berpengaruh terhadap peningkatan jumlah umbi per tanaman pada umur 12 MST : tidak berpengaruh terhadap peningkatan panjang umbi per tanaman pada umur $12 \mathrm{MST}$ : dan berpengaruh terhadap peningkatan berat segar umbi per tanaman pada umur 12 MST. Hasil Uji Beda Nyata Jujur (BNJ) pada taraf 5\%, hasilnya disajikan dalam Tabel 1.

Tabel 1. Pengaruh dosis pupuk $\mathrm{KCl}$ terhadap berat segar umbi per tanaman pada umur $12 \mathrm{MST}(\mathrm{kg})$ Perlakuan Rata-rata berat segar umbi $(\mathrm{kg})$

\begin{tabular}{lcc}
\hline $\mathrm{D}_{0}=\mathrm{KCl}$ dengan dosis $0 \mathrm{~kg} / \mathrm{ha}$ & 516,67 & $\mathrm{a}$ \\
$\mathrm{D}_{1}=\mathrm{KCl}$ dengan dosis $50 \mathrm{~kg} / \mathrm{ha}$ & 546,67 & $\mathrm{ab}$ \\
$\mathrm{D}_{2}=\mathrm{KCl}$ dengan dosis $100 \mathrm{~kg} / \mathrm{ha}$ & 566,67 & $\mathrm{ab}$ \\
$\mathrm{D}_{3}=\mathrm{KCl}$ dengan dosis $150 \mathrm{~kg} / \mathrm{ha}$ & 683,34 & $\mathrm{~b}$ \\
$\mathrm{D}_{4}=\mathrm{KCl}$ dengan dosis $200 \mathrm{~kg} / \mathrm{ha}$ & 593,34 & $\mathrm{ab}$ \\
\hline
\end{tabular}

Keterangan : Rata-rata berat segar umbi yang diikuti huruf sama berarti tidak nyata pada taraf $5 \%$ uji BNJ

\section{Produksi Per Hektar}

Hasil analisis ragam menunjukkan bahwa perlakuan dosis pupuk $\mathrm{KCl}$ berpengaruh terhadap peningkatan berat umbi sehat per tanaman pada umur $12 \mathrm{MST}$; berpengaruh terhadap penurunan berat umbi afkir per hektar pada umur $12 \mathrm{MST}$; berpengaruh terhadap peningkatan berat umbi yang dapat dipasarkan per hektar pada umur 12 MST ; berpengaruh nyata terhadap peningkatan berat segar umbi per hektar pada umur 12 MST. Sedangkan hasil uji BNJ disajikan berturut-turut dalam Tabel 2, Tabel 3, Tabel 4, dan Tabel 5

Tabel 2. Pengaruh dosis pupuk $\mathrm{KCl}$ terhadap berat umbi sehat per hektar pada umur $12 \mathrm{MST}(\mathrm{t})$

\begin{tabular}{lcc}
\hline \multicolumn{1}{c}{ Perlakuan } & Rata-rata berat umbi sehat $(\mathrm{t})$ & Hasil uji BNJ pada taraf 5\% \\
\hline $\mathrm{D}_{0}=\mathrm{KCl}$ dengan dosis $0 \mathrm{~kg} / \mathrm{ha}$ & 27,92 & $\mathrm{a}$ \\
$\mathrm{D}_{1}=\mathrm{KCl}$ dengan dosis $50 \mathrm{~kg} / \mathrm{ha}$ & 29,00 & $\mathrm{ab}$ \\
$\mathrm{D}_{2}=\mathrm{KCl}$ dengan dosis $100 \mathrm{~kg} / \mathrm{ha}$ & 29,80 & $\mathrm{abc}$ \\
$\mathrm{D}_{3}=\mathrm{KCl}$ dengan dosis $150 \mathrm{~kg} / \mathrm{ha}$ & 32,40 & $\mathrm{c}$ \\
$\mathrm{D}_{4}=\mathrm{KCl}$ dengan dosis $200 \mathrm{~kg} / \mathrm{ha}$ & 30,60 & $\mathrm{bc}$ \\
\hline
\end{tabular}

Keterangan : Rata-rata berat umbi sehat yang diikuti huruf sama berarti tidak nyata pada taraf $5 \%$ uji BNJ 
Tabel 2 menunjukkan bahwa pemberian pupuk $\mathrm{KCl}$ dengan dosis $150 \mathrm{~kg} / \mathrm{ha}$ akan menghasilkan berat umbi sehat terberat yaitu rata-rata $32,40 \mathrm{t} / \mathrm{ha}$, tetapi tidak berbeda nyata jika dibandingkan dengan dosis $100 \mathrm{~kg} / \mathrm{ha}$ yang menghasilkan berat umbi sehat rata-rata 29,80 t/ha dan dosis $200 \mathrm{~kg} / \mathrm{ha}$ yang menghasilkan berat umbi sehat rata-rata 30,60 t/ha.

Tabel 3. Pengaruh dosis pupuk $\mathrm{KCl}$ terhadap berat umbi afkir per hektar pada umur $12 \mathrm{MST}(\mathrm{t})$

\begin{tabular}{lcc}
\hline \multicolumn{1}{c}{ Perlakuan } & $\begin{array}{c}\text { Rata-rata berat umbi afkir } \\
(\mathrm{t})\end{array}$ & Hasil uji BNJ pada taraf $5 \%$ \\
\hline $\mathrm{D}_{0}=\mathrm{KCl}$ dengan dosis $0 \mathrm{~kg} / \mathrm{ha}$ & 3,40 & $\mathrm{~b}$ \\
$\mathrm{D}_{1}=\mathrm{KCl}$ dengan dosis $50 \mathrm{~kg} / \mathrm{ha}$ & 3,00 & $\mathrm{~b}$ \\
$\mathrm{D}_{2}=\mathrm{KCl}$ dengan dosis $100 \mathrm{~kg} / \mathrm{ha}$ & 2,40 & $\mathrm{a}$ \\
$\mathrm{D}_{3}=\mathrm{KCl}$ dengan dosis $150 \mathrm{~kg} / \mathrm{ha}$ & 2,40 & $\mathrm{a}$ \\
$\mathrm{D}_{4}=\mathrm{KCl}$ dengan dosis $200 \mathrm{~kg} / \mathrm{ha}$ & 2,40 & $\mathrm{a}$ \\
\hline
\end{tabular}

Keterangan : Rata-rata berat umbi afkirt yang diikuti huruf sama berarti tidak nyata pada taraf $5 \%$ uji $\mathrm{BNJ}$

Tabel 3 menunjukkan bahwa pem-berian pupuk KCl dengan dosis $150 \mathrm{~kg} / \mathrm{ha}$ menghasilkan berat umbi afkir paling ringan yaitu rata-rata 2,40 t/ha jika dibandingkan dengan dosis $0 \mathrm{~kg} / \mathrm{ha}$ yang menghasilkan berat umbi afkir paling berat yaitu rata-rata $3,40 \mathrm{t} / \mathrm{ha}$, tetapi tidak nyata jika dibandingkan dengan dosis $100 \mathrm{~kg} / \mathrm{ha}$ dan $200 \mathrm{~kg} / \mathrm{ha}$ yang menghasilkan ma-sing-masing 2,40 t/ha.

Tabel 4. Pengaruh dosis pupuk $\mathrm{KCl}$ terhadap berat umbi yang dapat dipasarkan per hektar pada umur $12 \operatorname{MST}(\mathrm{t})$

\begin{tabular}{lcc}
\hline \multicolumn{1}{c}{ Perlakuan } & $\begin{array}{c}\text { Rata-rata berat umbi yang } \\
\text { dapat dipasarkan }(\mathrm{t})\end{array}$ & $\begin{array}{c}\text { Hasil uji BNJ } \\
\text { pada taraf } 5 \%\end{array}$ \\
\hline $\mathrm{D}_{0}=\mathrm{KCl}$ dengan dosis $0 \mathrm{~kg} / \mathrm{ha}$ & 24,32 & $\mathrm{a}$ \\
$\mathrm{D}_{1}=\mathrm{KCl}$ dengan dosis $50 \mathrm{~kg} / \mathrm{ha}$ & 26,16 & $\mathrm{ab}$ \\
$\mathrm{D}_{2}=\mathrm{KCl}$ dengan dosis $100 \mathrm{~kg} / \mathrm{ha}$ & 27,40 & $\mathrm{abc}$ \\
$\mathrm{D}_{3}=\mathrm{KCl}$ dengan dosis $150 \mathrm{~kg} / \mathrm{ha}$ & 30,00 & $\mathrm{c}$ \\
$\mathrm{D}_{4}=\mathrm{KCl}$ dengan dosis $200 \mathrm{~kg} / \mathrm{ha}$ & 28,20 & $\mathrm{bc}$ \\
\hline
\end{tabular}

Keterangan : Rata-rata berat umbi yang dapat dipasarkan yang diikuti huruf sama berarti tidak nyata pada taraf $5 \%$ uji BNJ

Tabel 4 menunjukkan bahwa pemberian pupuk $\mathrm{KCl}$ dengan dosis $150 \mathrm{~kg} / \mathrm{ha}$ akan menghasilkan berat umbi yang dapat dipasarkan paling berat yaitu rata-rata 30,00 t/ha jika dibandingkan dengan dosis $0 \mathrm{~kg} / \mathrm{ha}$ yang menghasilkan berat umbi yang dapat dipasarkan paling ringan yaitu rata-rata $24,32 \mathrm{t} / \mathrm{ha}$, tetapi tidak nyata jika dibandingkan dengan dosis $100 \mathrm{~kg} / \mathrm{ha}$ dan $200 \mathrm{~kg} / \mathrm{ha}$ yang menghasilkan masingmasing 27,40 t/ha dan 28,20 t/ha.

Tabel 5. Pengaruh dosis pupuk KCl terhadap berat segar umbi per hektar pada umur 12 MST (t)

\begin{tabular}{lrc}
\hline \multicolumn{1}{c}{ Perlakuan } & $\begin{array}{r}\text { Rata-rata berat } \\
\text { umbi }(\mathrm{t})\end{array}$ & $\begin{array}{c}\text { Hasil uji BNJ } \\
\text { pada taraf } 5 \%\end{array}$ \\
\hline $\mathrm{D}_{0}=\mathrm{KCl}$ dengan dosis $0 \mathrm{~kg} / \mathrm{ha}$ & 28,80 & $\mathrm{a}$ \\
$\mathrm{D}_{1}=\mathrm{KCl}$ dengan dosis $50 \mathrm{~kg} / \mathrm{ha}$ & 29,80 & $\mathrm{ab}$ \\
$\mathrm{D}_{2}=\mathrm{KCl}$ dengan dosis $100 \mathrm{~kg} / \mathrm{ha}$ & 30,80 & $\mathrm{abc}$ \\
$\mathrm{D}_{3}=\mathrm{KCl}$ dengan dosis $150 \mathrm{~kg} / \mathrm{ha}$ & 33,20 & $\mathrm{c}$ \\
$\mathrm{D}_{4}=\mathrm{KCl}$ dengan dosis $200 \mathrm{~kg} / \mathrm{ha}$ & 32,20 & $\mathrm{bc}$ \\
\hline
\end{tabular}

Keterangan : Rata-rata berat segar umbi yang diikuti huruf sama berarti tidak nyata pada taraf 5\% uji BNJ

Tabel 5 menunjukkan bahwa pem-berian pupuk $\mathrm{KCl}$ dengan dosis $150 \mathrm{~kg} / \mathrm{ha}$ menghasilkan berat segar umbi yang paling berat yaitu rata-rata 33,20 t/ha jika dibandingkan dengan dosis $0 \mathrm{~kg} / \mathrm{ha}$ yang menghasilkan berat segar umbi yang paling ringan yaitu rata-rata $28,80 \mathrm{t} / \mathrm{ha}$, tetapi tidak nyata 
jika dibandingkan dengan dosis $100 \mathrm{~kg} / \mathrm{ha}$ dan $200 \mathrm{~kg} / \mathrm{ha}$ yang menghasilkan masing-masing 30,80 t/ha dan 32,20 t/ha.

\section{PEMBAHASAN}

Hasil penelitian menunjukkan bahwa pemberian pupuk $\mathrm{KCl}$ tidak berpengaruh nyata terhadap peningkatan panjang batang utama. Hal ini mungkin karena unsur $\mathrm{K}$ yang diberikan lebih bannyak digunakan untuk pembentukan organ penyim-panan terutama pembentukan umbi daripada pembentukan organ vegetatif (Ismunadji et al., 1976).

Di samping itu, diduga ketersediaan unsur K dalam tanah telah mencukupi kebutuhan tanaman sehingga penambahan $\mathrm{K}$ melalui pemberian $\mathrm{KCl}$ tidak memberikan pengaruh nyata terhadap panjang batang utama. Rata-rata panjang batang utama pada umur 11 MST adalah $125,23 \mathrm{~cm}$ dengan pertumbuhan panjang batang utama sebagaimana disajikan dalam Gambar 1.

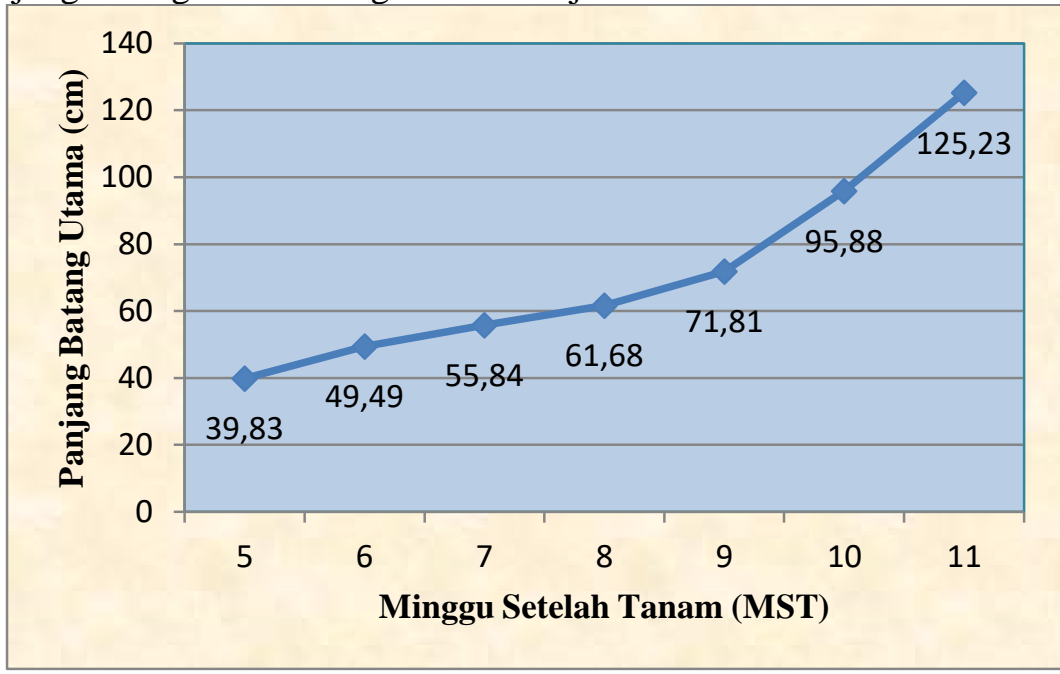

Gambar 1. Pertumbuhan panjang batang utama ubi jalar

Tidak adanya pengaruh pemberian pupuk $\mathrm{KCl}$ terhadap jumlah cabang tersebut di atas diduga karena jumlah cabang lebih dipengaruhi oleh ketersediaan unsur $\mathrm{N}$ di dalam tanah yang rendah. Menurut Lakitan (2007) rendahnya unsur N mengakibatkan proses pembentukan organ vegetatif akan terganggu. Di samping itu, pemberian pupuk dasar N yang sama sebesar $100 \mathrm{~kg} / \mathrm{ha}$ pada semua petak percobaan, diduga akan memberikan respon yang sama terhadap pertumbuhan vegetatif tanaman dalam hal ini jumlah cabang ubi jalar. Rata-rata jumlah cabang pada umur 11 MST adalah 10,55 batang dengan pertum-buhan jumlah cabang sebagaimana disajikan dalam Gambar 2.

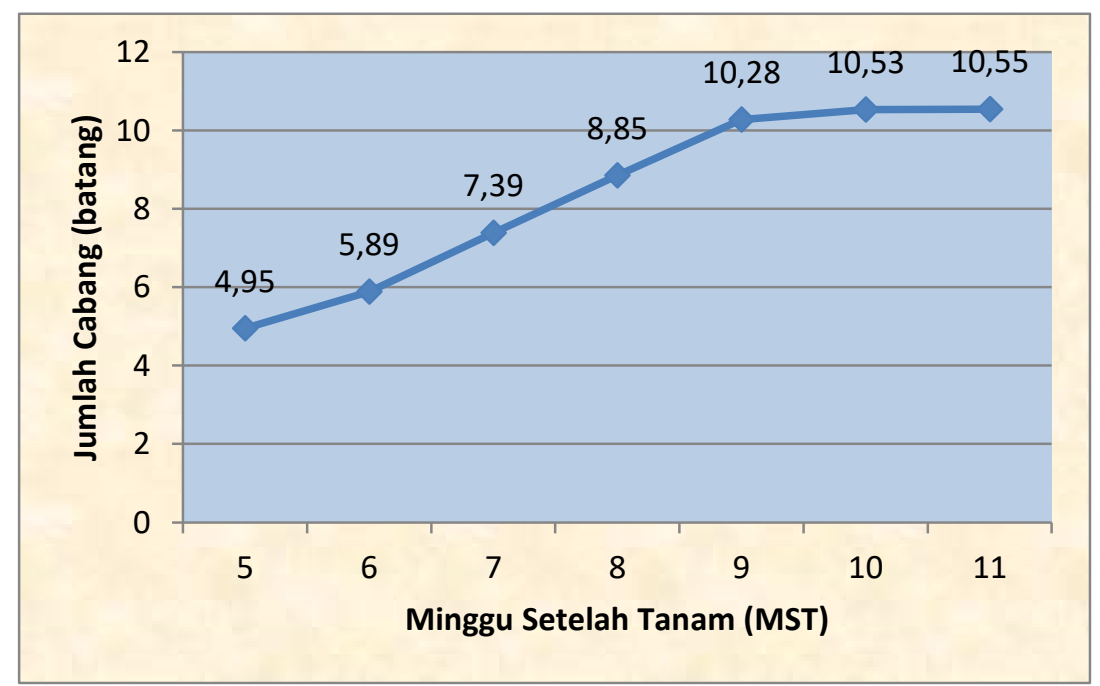

Gambar 2. Pertumbuhan jumlah cabang ubi jalar 
Terjadinya pengaruh nyata terhadap pertumbuhan jumlah daun tersebut di atas menunjukkan bahwa jumlah $\mathrm{N}$ yang tersedia yang diperoleh dari $\mathrm{N}$ yang ada di dalam tanah dan $\mathrm{N}$ yang berasal dari pemberian pupuk urea sebagai pupuk dasar sebanyak $100 \mathrm{~kg} / \mathrm{ha}$, telah dapat dimanfaatkan dengan baik oleh tanaman untuk menghasilkan jumlah daun yang lebih banyak terutama pada umur 6, 7, 8, dan 9 MST.

Setelah umur 9 MST, nampaknya ketersediaan $\mathrm{N}$ berkurang sehingga tanaman tidak dapat menghasilkan jumlah daun yang lebih banyak secara nyata terutama pada umur 10 MST dan 11 MST. Hal ini sesuai dengan pendapat Lakitan (2007) bahwa kekurangan unsur $\mathrm{N}$ akan menghambat proses pertumbuhan vegetatif terutama pembentukan daun. Rata-rata jumlah daun pada umur 11 MST adalah 10,55 helai dengan pertumbuhan jumlah daun sebagaimana disajikan dalam Gambar 3

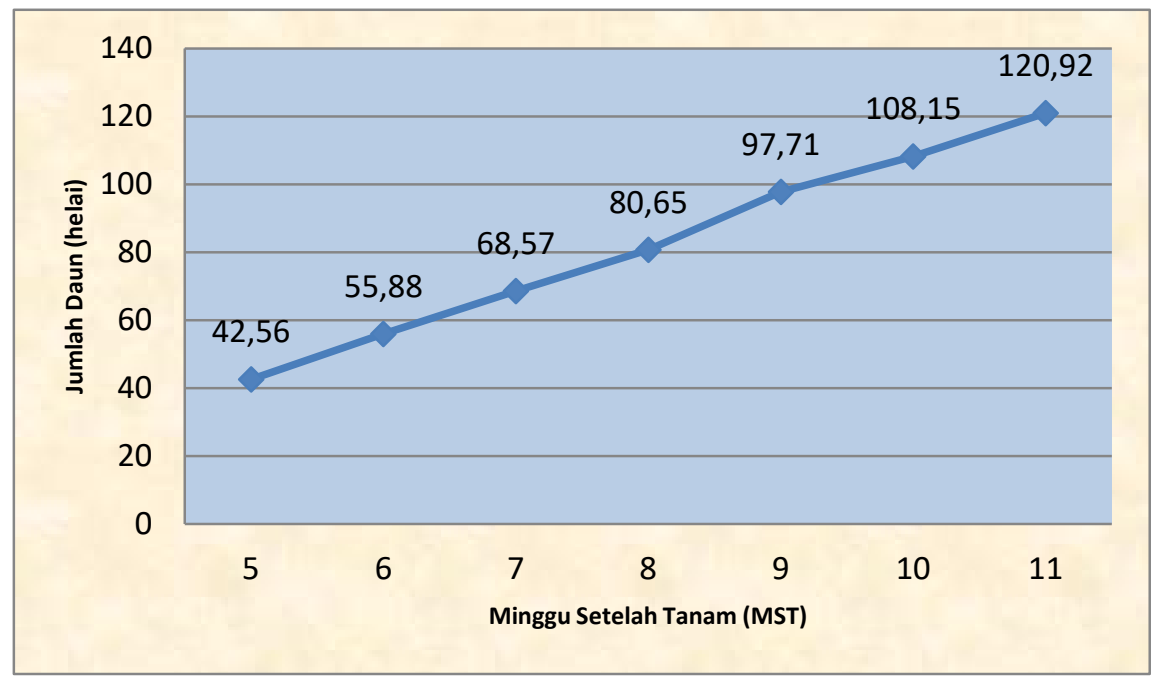

Gambar 3. Pertumbuhan jumlah daun ubi jalar

Tanaman ubi jalar dapat dipanen untuk hasil secara umum pada umur 16 - 17 MST sedangkan pengamatan diameter umbi dilakukan saat tanaman berumur 12 MST. Hal inilah yang menyebabkan tidak adanya pengaruh nyata terhadap diameter umbi karena umbi yang di-panen umur 12 MST tersebut diduga masih relatif kecil dan belum mengarahkan hasil fotosintesisnya untuk pembesaran umbi. Kenyataan ini sesuai dengan pendapat Wargiono (1980) bahwa pertumbuhan umbi optimal terjadi pada tanaman yang berumur $2-3$ minggu sebelum panen.

Tidak terjadinya pengaruh nyata terhadap jumlah umbi diduga karena pengamatan dilakukan pada saat tanaman masih berumur relatif muda (12 MST) sehingga perkembangan jumlah umbi belum maksimal. Di samping itu diduga karena jumlah umbi lebih dipengaruhi oleh pemupukan phospor daripada pemu-pukan kalium (Ignatief dan Page, 1958 dalam Wahyudi, 2011).

Menurut Junaedi (2005) panjang umbi berkorelasi positif dengan diameter umbi. Hal ini berarti jika pemberian pupuk $\mathrm{KCl}$ tidak ber-pengaruh nyata terhadap diameter umbi maka pengaruh pupuk $\mathrm{KCl}$ juga tidak nyata terhadap panjang umbi.

Pemberian pupuk $\mathrm{KCl}$ dengan dosis yang terus meningkat sampai $150 \mathrm{~kg} / \mathrm{ha}$ berdampak terhadap ketersediaan unsur K yang semakin banyak di dalam tanah sehingga akan semakin banyak pula unsur $\mathrm{K}$ yang diserap tanaman, Hal inl diduga yang menyebabkan terjadinya peningkatan berat umbi segar per tanaman.

Selanjutnya, tidak terjadinya peningkatan berat umbi segar pada pemberian pupuk $\mathrm{KCl}$ dengan dosis $200 \mathrm{~kg} / \mathrm{ha}$, diduga karena tanaman mengalami gejala pemupukan $\mathrm{K}$ yang berlebihan, yaitu keadaan dimana tanaman terus menerus menyerap hara secara berlebihan dan tidak berdampak pada peningkatan hasil (Tisdale dan Nelson, 1965).

Peningkatan berat umbi sehat secara nyata pada dosis $150 \mathrm{~kg} / \mathrm{ha}$ diduga karena pada dosis tersebut jumlah unsur $\mathrm{K}$ yang berfungsi dalam translokasi fotosintat tanaman sudah tersedia cukup untuk pertumbuhan dan perkembangan umbi ubi jalar. Sedangkan tidak terjadinya peningkatan berat umbi 
sehat pada dosis $200 \mathrm{~kg} / \mathrm{ha}$ diduga karena tanaman mengalami gejala pemupukan $\mathrm{K}$ yang berlebihan (luxury consumtion of potassium).

Penurunan berat umbi afkir akibat pemberian pupuk $\mathrm{KCl}$ dengan dosis $150 \mathrm{~kg} / \mathrm{ha}$ diduga karena pada dosis tersebut ketersediaan unsur $\mathrm{K}$ telah mencukupi sehingga berat umbi afkir yang dihasilkan berkurang. Menurut Tisdale dan Nelson (1965) kalium berperan aktif dalam kegiatan-kegiatan fisiologis terutama dalam metabolisme karbohidrat.

Pemberian pupuk $\mathrm{KCl}$ dengan dosis $150 \mathrm{~kg} / \mathrm{ha}$ ternyata juga me-ningkatkan berat umbi yang dapat dipasarkan. Hal ini diduga karena pada dosis tersebut jumlah unsur $\mathrm{K}$ yang tersedia telah mencukupi untuk pertumbuhan dan perkembangan umbi ubi jalar. Kenyataan ini didukung oleh pendapat Widodo (1987) bahwa pembentukan dan pembesaran umbi sangat memerlukan ketersdiaan unsur hara terutama kalium yang cukup. Pemberian pupuk $\mathrm{KCl}$ sebesar $150 \mathrm{~kg} / \mathrm{ha}$ diduga mampu menambahkan unsur hara $\mathrm{K}$ yang dapat dimanfaatkan tanaman sehingga berat umbi yang dapat dipasarkan lebih banyak.

Terjadinya peningkatan berat segar umbi per hektar pada dosis $150 \mathrm{~kg} / \mathrm{ha}$ diduga karena pada dosis tersebut jumlah unsur $\mathrm{K}$ yang tersedia meningkat sehingga dapat dimanfaatkan tanaman untuk pertumbuhan dan perkembangan tanaman terutama peningkatan berat segar umbi ubi jalar per hektar.

\section{KESIMPULAN}

1. Pemberian pupuk $\mathrm{KCl}$ tidak berpengaruh nyata terhadap semua parameter pertumbuhan ubi jalar yang diamati yaitu panjang batang utama, jumlah cabang, dan jumlah daun.

2. Pemberian pupuk $\mathrm{KCl}$ berpengaruh nyata terhadap produksi per tanaman ubi jalar yaitu berat segar umbi pertanaman, tetapi tidak nyata terhadap diameter umbi per tanaman, jumlah umbi per tanaman, dan panjang umbi per tanaman.

3. Pemberian pupuk $\mathrm{KCl}$ berpengaruh nyata terhadap semua para-meter produksi ubi jalar yaitu berat umbi sehat per hektar, berat umbi afkir per hektar, berat umbi yang dapat dipasarkan, dan berat segar umbi per hektar.

4. Dosis pupuk $\mathrm{KCl}$ terbaik adalah $150 \mathrm{~kg} / \mathrm{ha}$ karena dapat menghasilkan berat segar umbi tertinggi yaitu $683,34 \mathrm{~kg} /$ tanaman, berat umbi sehat tertinggi yaitu $32,40 \mathrm{t} / \mathrm{ha}$, berat umbi afkir terendah yaitu $2,40 \mathrm{t} / \mathrm{ha}$, berat umbi yang dapat dipasarkan tertinggi yaitu 30,0 t/ha, dan berat segar umbi tertinggi yaitu 33,20 t/ha.

\section{DAFTAR PUSTAKA}

Gaspersz, V., 1991. Teknik Analisis Dalam Penelitian Percobaan. Tarsito, Bandung. 623 hal

Ismunadji, M., S. Partohardjono dan Satsijati. 1976. Peranan kalium dalam peningkatan produksi tanaman pangan. Kalium dan Tanaman Pangan: Problem dan Prospek. Lembaga Pusat Penelitian Pertanian, Bogor. Edisi Khusus. 2: 1-16

Juanda, D.J.S. dan B. Cahyono. 2002. Ubi jalar: Budidaya dan Analisis Usaha Tani. Kanisius. Yogyakarta. 92 hal.

Junaedi, E., 2005. Pengaruh Pupuk N-P-K Terhadap Status Nitrat dan Kalium Tajuk serta Pertumbuhan dan Produksi Ubi Jalar (Ipomoea batatas L.). Departemen Budidaya Pertanian. Fakultas Pertanian Institut Pertanian Bogor. 55 hal.

Lakitan B, 2007. Fisiologi Pertumbuhan dan Perkembangan Tanaman. Raja Grafindo Persada. Jakarta. 27 hal.

Limbeng, M., 2011. Pengaruh Dosis Pupuk Kalium Terhadap Pertumbuhan Ubi Rambat, diunduh pada 19 September 2014.

Paturohman, E dan Sumarno, S., 2016. Pemupukan Sebagai Penentu Produktivitas Ubi Jalar. Iptek Tanaman Pangan, 10(2), 77-84. 
Rukmana, R. 2004. Ubi Jalar. Budidaya dan Pasca Panen. Kanisius. Yogyakarta. 66 hal.

Rulina, D., 2010. Pengaruh Pemberian Dosis Pupuk Kalium Dan Macam Cara Peletakan Stek Terhadap Pertumbuhan Dan Hasil Ubi Jalar (Ipomoea ba-tatas (L.) Lam.). Skripsi. Fakultas Pertanian Universitas Sebelas Maret, Surakarta.

Sarwono, B. 2007. Ubi jalar: Cara Budidaya yang Tepat, Efisien, dan Ekonomis. Penebar Swadaya. Jakarta. 85 hal.

Steel, R.G.D. dan J.H. Torrie, 1989. Prinsip dan Prosedur Statistika: Suatu Pendekatan Biometrik.Terjemahan Bambang Sumantri (IPB). PT Grame-dia, jakarta. 748 hal.

Sugandi, E. dan Sugiarto, 1994. Rancangan Percobaan: Teori dan Aplikasi Offset, Yogyakarta. 236 hal.

Sumarno, 1981. Pengkajian Singkat Kesuburan Ubi Jalar. Departemen Ilmu Tanah Fakultas Pertanian Universitas Brawijaya, Malang.

Tisdale, S.I and Nelson, W.L., 1965. Soil Fertilityand Fertilizer. The Mac Millan C., New York. 430 p.

Wahyudi, 2011. Pengaruh Pemupukan KCl Kedua dan Pemberian Jerami Terhadap Pertumbuhan dan Produksi Ubi Jalar (Ipomoea batatas L.) Klon Ayamurashake. Departemen Agronomi dan Hortikultura. Fakultas Pertanian Institut Pertanian Bogor.

Wargiono, J. 1980. Ubi Jalar dan Cara Bercocok Tanamnya. Buletin Teknik No 5. Lembaga Pusat Penelitian Bogor. 37 hal.

Widodo, Y.1987. Pengaruh Pembe-rian Jerami dan Saat Peng-guludan Terdapa Pertumbuhan dan Hasil Ubi Jalar. Pe-nelitian Palawaija. 2(1): 26-32. 